JKKP : Jurnal Kesejahteraan Keluarga dan Pendidikan

http://doi.org/10.21009/JKKP

DOI:doi.org/10.21009/JKKP.051.08

E-ISSN : 2597-4521

\title{
EFEKTIVITAS TEKNIK MANGKUK IKAN ATAU AKUARIUM (FISH BOWL) UNTUK MENINGKATKAN HASIL BELAJAR IPS PADA SISWA KELAS V A SDN 16 CAKRANEGARA TAHUN PELAJARAN 2016/2017
}

\author{
1,a)Ni Komang Sri Widari, 2,b)Nur Hasanah, ${ }^{3, c) S i t i ~ I s t i n i n g s i h ~}$ \\ Email: ningistie@yahoo.com \\ 1,2,3) Program Studi S1 PGSD, Fakultas Keguruan Dan IImu Pendidikan Universitas Mataram
}

\begin{abstract}
Abstrak
Penelitian ini dilatarbelakangi rendahnya hasil belajar IPS siswa kelas V A di SDN 16 Cakranegara. Hal ini disebabkan pembelajaran masih terpusat pada guru (Teacher Centered) dan teknik serta metode yang digunakan monoton. Guru biasanya hanya mengajar dengan metode ceramah saja, dan tidak di dukung dengan sarana dan prasarana yang memadai. Masalah penelitian ini adalah bagaimanakah Efektivitas Teknik Mangkuk Ikan atau Akuarium (Fish Bowl) dapat meningkatkan hasil belajar IPS siswa kelas V A SDN 16 Cakranegara Tahun Pelajaran 2016/2017?. Tujuan penelitian ini adalah untuk meningkatkan hasil belajar IPS siswa kelas V A SDN 16 Cakra Negara Tahun Pelajaran 2016/2017 dengan menerapkan teknik Mangkuk Ikan Atau Akuarium (Fish Bowl). Jenis penelitian ini adalah penelitian tindakan kelas yang dilaksanakan dalam 2 siklus. Setiap siklus terdiri dari tahap perencanaan, pelaksanaan, tindakan, observasi, dan evaluasi serta refleksi. Metode yang digunakan dalam mengumpulkan data dalam penelitian ini adalah metode observasi, dokumentasi dan tes. Pada siklus I diperoleh nilai rata-rata 75,375 dengan ketuntasan klasikal 70,83\% dan skor rata-rata aktivitas siswa 53 dengan kategori cukup aktif. Pada siklus II data hasil belajar dan aktivitas siswa mengalami peningkatan yakni rata-rata 82,791 dengan ketuntasan klasikal $87,5 \%$ dan skor rata-rata aktivitas belajar siswa 58,5 dengan kriteria aktif. Dengan demikian dapat disimpulkan bahwa Efektivitas Teknik Mangkuk Ikan atau Akuarium (Fish Bowl) dapat meningkatkan hasil belajar IPS siswa kelas V A SDN 16 Cakranegara Tahun Pelajaran 2016/2017.
\end{abstract}

Kata Kunci: Efektivitas, Teknik "Mangkuk Ikan atau Akuarium (Fish Bowl)", hasil belajar IPS.

\section{The Effectivenes of Fish Bowl Or Fish Bowl Techniques To Improve The Learning Outcomes Of Ips In Grade Students V A and 16 Cakranegara Academic Year 2016/2017}

\begin{abstract}
Background of this research is the low social learning outcomes on students fifth grade at SDN 16 Cakranegara, it is caused by learning process focus on teaccher (Teacher Centered) and they used monoton method. Teacher usually teach only usuhg speech method and they didn't support by the appropriate facilities. The problem in this research is how the efectivness of bowl fish teachnique could improve social learning outcomes on fifth grade students at SDN 16 Cakranegara in 2016 to 2017 ? The purpose is to improve social learning outcomes on fifth grade students in 2016 to 2017 by using bowl fish technique or aquarum. This is a base calssrom research in two cydes each cycle consist of planning, implementation, action, observation, and evaluation, reflection as well. The method collecting data are observation, documentation and test. In the frist cycle the result is on average 75,375 with percentage $70,83 \%$ and the scores for activities of students are 53 categories active enough. In second cycle the students having an increase on average 82,791 categories active. The conelusion is the efectivness of
\end{abstract}


bowl fish technique could improve social learing outcomes on fifth grade students at SDN 16 Cakranegara in 2016 to 2017.

Key Word : The efectivness, techniques of "bowl fish technique or aquarium", and social learing out comes.

\section{PENDAHULUAN}

Menurut R. Gagne (Susanto, 2013: 1) belajar dapat didefinisikan sebagai suatu proses di mana suatu organisme berubah perilakunya sebagai akibat pengalaman. Belajar dan mengajar merupakan dua konsep yang tidak dapat dipisahkan satu sama lain. Dua konsep ini menjadi terpadu dalam satu kegiatan dimana terjadi interaksi antara guru dengan siswa, serta siswa dengan siswa saat proses pembelajaran berlangsung. Dalam proses belajar mengajar, tipe hasil belajar yang diharapkan dapat dicapai siswa penting diketahui oleh guru, agar guru dapat merancang/mendesain pengajaran secara tepat dan penuh arti. Disini guru dapat menggunakan teknik pembelajaran sangat berguna, baik guru maupun siswa pada proses pembelajaran.

Pendidikan IPS merupakan salah satu mata pelajaran yang dapat memberikan wawasan pengetahuan yang luas mengenai masyarakat lokal maupun global sehingga mampu hidup bersama-sama dengan masyarakat lainnya. Sebagai bidang studi yang diberikan pada jenjang pendidikan di lingkungan persekolahan, bukan hanya memberikan bekal pengetahuan saja, tetapi juga memberikan bekal nilai, sikap serta keterampilan dalam kehidupan siswa dimasyarakat, bangsa, negara, dalam berbagai karakteristik. Jadi pendidikan IPS bukan hanya sekedar membekali siswa dengan berbagai informasi yang bersifat hafalan (kognitif) saja, akan tetapi harus mampu mengembangkan keterampilan berpikir, bertindak dan nilai yang terkandung di dalamnya agar siswa mampu mengkaji berbagai kenyataan sosial beserta masalahnya.

Dalam pengamatan peneliti di SDN 16 Cakranegara pada kelas V A/I jumlah muridnya ada 24 orang yang terdiri dari 13 siswa laki-laki dan 11 siswi perempuan, dari hasil belajar pada mata pelajaran IPS bisa dikatakan belum mencapai KKM, sedangkan KKM yang sudah ditentukan oleh pihak sekolah yaitu 75. Jadi jika kita melihat nilai dari hasil MID semester I kemarin terdapat 14 siswa atau 58,33\% yang nilainya melampui KKM dan sisanya ada 10 siswa atau $41,67 \%$ yang mendapat nilai dibawah KKM, adapun hal-hal yang menyebabkan rendahnya hasil belajar siswa yang masih ditemui di kelas V A pada pelajaran IPS sebagai berikut: 1) Dalam proses pembelajaran siswa jarang mengajukan pertanyaan ataupun memberikan tanggapan; 2) Dalam proses pembelajaran sebagian besar siswa kurang aktif, hal ini terlihat dari aktifitas siswa yang tidak memperhatikan guru yang sedang menyampaikan materi pelajaran; 3) Siswa cepat merasa bosan dalam proses pembelajaran. Hal ini terlihat dari aktivitas siswa yang sibuk dengan kegiatannya sendiri, seperti bermain dengan teman di kelas; 4) Sebagian siswa ada yang mengantuk ketika guru menyampaikan materi pelajaran dan materi terlalu luas.

Berdasarkan penjelasan di atas, maka dapat dipahami bahwa hasil belajar siswa dalam belajar IPS tergolong rendah. Untuk itu, dalam penelitian ini penulis akan menggunakan teknik mangkuk ikan atau akuarium (Fish Bowl) untuk meningkatkan hasil belajar IPS pada siswa kelas V A SDN 16 Cakranegara. Menurut Warsono dan Hariyanto (2013: 36) menjelaskan ada bermacam teknik untuk mendapatkan keaktifan dalam belajar, salah satunya adalah dengan menggunakan teknik mangkuk ikan atau akuarium (Fish Bowl) yang dirasa peneliti dapat membantu meningkatkan hasil belajar siswa.

Dalam teknik pembelajaran ini, guru memberikan sebuah kartu indeks (index card) pada masing-masing siswa, kemudian guru membagi siswa menjadi beberapa bagian kelompok dan masing-masing siswa diminta untuk menuliskan sebuah pertanyaan diatas kartu indeks tersebut terkait bahan ajar yang baru saja diterimannya. Siswa dapat menuliskan pertanyaan dan mengumpulkan kartu indeks yang telah ditulisi dengan pertanyaan dan mengumpulkannya dalam mangkuk ikan atau akuarium kosong yang disediakan oleh guru. Tugas ini dapat juga dijadikan sebagai perkerjaan rumah dan keesokan harinya dikumpulkan. Kemudian guru secara acak mengambil sejumlah kartu indeks yang sudah ditulisi pertanyaan tersebut, dan dapat membagikan kepada setiap kelompok untuk menjawab pertanyaan yang diajukan oleh temannya sendiri. Jika sering menggunakan kartu indeks, variasi tempat duduk dan melatih siswa untuk tampil persentasi didepan kelas, untuk guru akan memiliki bank soal dengan 
kartu yang dapat dipergunakan sewaktu-waktu sedangkan untuk siswa dapat membuat mereka untuk belajar latihan berfikir yang tidak hanya dikelas saja melainkan dirumah pun bisa kemudian keesokan harinya dibawa, karena paling tidak siswa harus mengingat materi yang baru diterimanya atau membuka buku membaca secara ulang untuk dapat menuliskan pertanyaan yang nantinya akan mendapat nilai tambahan bagi siswa yang mengerjakan sebaliknya kepada siswa yang tidak mengerjakan maka tidak akan mendapat nilai, jika ini dilakukan secara berkelanjutan dan divariasikan dengan teknik, metode, dan media yang lain maka aktivitas dan hasil belajar siswa dapat tercapai dengan maksimal.

Dengan demikian ini menjadi salah satu penelitian yang menarik untuk dilakukan karena sepengetahuan peneliti teknik ini belum ada yang melakukan penelitian di S1-PGSD tetapi untuk di luar S1-PGSD sudah ada dan hasilnya pun dapat meningkatkan aktivitas belajar sains. Maka pada penelitian kali ini yaitu dengan teknik mangkuk ikan atau akuarium (Fish Bowl) pada mata pelajaran IPS yang materinya luas dan biasanya berada pada akhir jam pelajaran, diharapkan dengan cara seperti ini dapat mempengaruhi untuk meningkatkan hasil belajar siswa kelas V A pada mata pelajaran IPS.

Berdasarkan latar belakang teknik mangkuk ikan atau akuarium Fish bowl diatas, maka penulis tertarik untuk melakukan penelitian yang akan dituangkan dalam bentuk penelitian tindakan kelas dengan judul "Efektivitas Teknik Mangkuk Ikan Atau Akuarium (Fish Bowl) Untuk Meningkatkan Hasil Belajar IPS Pada Siswa Kelas V A SDN 16 Cakranegara Tahun Pelajaran 2016/2017"

Berdasarkan latar belakang, maka perlu kiranya dilakukan Penelitian Permasalahan yang akan diteliti dalam penelitian ini, yaitu: "bagaimanakah Efektivitas Teknik Mangkuk Ikan atau Akuarium (Fish Bowl) dapat meningkatkan hasil belajar IPS Pada Siswa Kelas V A SDN 16 Cakranegara Tahun Pelajaran 2016/2017?

Adapun cara pemecahan masalah dalam penelitian ini yaitu rendahnya aktivitas belajar siswa pada mata pelajaran IPS kelas V A SDN 16 Cakranegara Tahun Pelajaran 2016/2017 disebabkan karena guru hanya menggunakan metode ceramah dan demonstrasi saja, sehingga aktivitas belajar siswa menjadi kurang aktif dan siswa merasa bosan serta tidak nyaman berada di kelas. Hal ini juga menyebabkan rendahnya hasil belajar pada mata pelajaran IPS kelas V A SDN 16 Cakranegara Tahun Pelajaran 2016/2017, salah satunya disebabkan karena dalam proses pembelajaran dalam kelas masih menggunakan pendekatan yang hanya berpusat pada guru (teacher center) dan kurangnya variasi gaya mengajar, akibatnya siswa tidak terlibat secara aktif.

Jika hal ini dibiarkan maka kualitas pembelajaran akan semakin menurun dan harus segera dicarikan solusinya. Efektivitas Teknik Mangkuk Ikan atau Akuarium (Fish Bowl) dalam pembelajaran diharapkan menjadi alternative/solusi dalam mengatasi masalah yang dikemukakan di atas.

Teknik pembelajaran ini merupakan sebuah teknik yang yang menitik beratkan pada kemampuan seorang siswa untuk mengembangkan potensi yang ada dalam dirinya. Teknik mangkuk ikan atau akuarium (Fish Bowl) merupakan cara yang digunakan untuk membuat siswa aktif belajar baik disekolah maupun dirumah (bida di jadikan PR jika waktunya tidak cukup) dengan adanya kartu indeks yang diberikan serta variasi tempat duduk yang dapat menarik minat siswa untuk mengikuti proses pembelajaran. Teknik ini juga melatih siswa untuk membuat pertanyaan pada kartu indeks kemudian akan mencari solusi/jawaban yang akan dibawakan/dipersentasikan didepan kelas, disini juga guru dapat menanamkan sikap hidup sosial sejak dini. Metode ini menuntut siswa untuk berperan aktif dan bersemangat dalam proses pembelajaran sehingga berdampak pada hasil belajar yang meningkat.

Tujuan yang ingin dicapai dalam penelitian ini adalah "Untuk meningkatkan hasil belajar IPS dengan menerapkan Efektivitas Teknik Mangkuk Ikan atau Akuarium (Fish Bowl) pada siswa kelas V A SDN 16 Cakranegara Tahun Pelajaran 2016/2017".

Adapun manfaat yang akan diperoleh dalam penelitian ini yaitu:

1. Bagi Mahasiswa atau peneliti

Berpengalaman langsung dalam mengembangkan pembelajaran yang inovatif, kreatif, efektif dan menyenangkan sebagai salah satu upaya meningkatkan mutu pendidikan.

2. Bagi Guru 
Sebagai bahan masukan bagi guru kelas bahwa pada pelajaran IPS agar dapat menggunakan Teknik Mangkuk Ikan Atau Akuarium (Fish Bowl) Untuk Meningkatkan Hasil Belajar IPS Pada Siswa Kelas V A SDN 16 Cakranegara Tahun Pelajaran 2016/2017"

3. Bagi Siswa

Meningkatkan keaktifan siswa saat proses belajar-mengajar dengan begitu hasil belajarnya pun meningkat.

4. Bagi Sekolah

Bertambahnya variasi teknik pembelajaran dalam upaya peningkatan hasil belajar siswa di sekolah serta mutu pendidikan pada umumnya.

\section{TINJAUAN PUSTAKA}

1. Teknik Pembelajaran

a. Pengertian Teknik Pembelajaran

Teknik pembelajaran seringkali di samakan artinya dengan metode pembelajaran. Teknik pembelajaran juga adalah cara yang dilakukan guru atau pendidik untuk menerapkan suatu metode yang sudah disesuaikan dengan materi, metode teknik, media dan keadaan siswa agar tujuan pembelajaran dapat tercapai semaksimal mungkin dengan harapan dapat membantu siswa dalam proses belajar mengajar dan dapat meningkatkan aktivitas dan hasil belajarnya.

b. Macam-macam Teknik Pembelajaran

1) Teknik Pembelajaran Pertanyaan Atau Kuis/Tes (Quiz/Test Questions) adalah cara yang digunakan guru saat proses pembelajaran dengan mengadakan kuis yang dapat menarik minat belajar dan membuat siswa aktif.

2) Teknik Pembelajaran Setiap Siswa Dapat Jadi Guru (Everyone is a Teacher) adalah merupakan cara yang digunakan guru untuk memberi kesempatan kepada seluruh siswanya untuk berekpresi/menyampaikan apa yang mereka ketahui tentang materi yang sedang dipelajari didepan teman-teman mereka.

3) Teknik pembelajaran Pilah Kartu (Card Sort) adalah merupakan cara guru untuk membuat siswa aktif dalam proses pembelajaran dengan materi yang sudah disediakan pada kartu.

4) Teknik Mangkuk Ikan Atau Akuarium (Fish Bowl), adalah merupakan cara yang digunakan untuk membuat siswa aktif belajar baik disekolah maupun dirumah dengan adanya kartu indeks yang diberikan serta variasi tempat duduk yang dapat menarik minat siswa untuk mengikuti proses pembelajaran.

a) Ciri-ciri Teknik Mangkuk Ikan Atau Akuarium (Fish Bowl) dari pendapat para ahli diatas yaitu: Menggunakan kartu indeks; Terdapat variasi tempat duduk; Guru dapat memiliki lebih banyak bank soal; Membuat siswa aktif belajar di sekolah dan di rumah karena sewaktuwaktu bila waktu tidak cukup pertanyaan dapat dibuat dirumah; Pembelajaran menjadi menyenangkan.

b) Penerapan teknik mangkuk ikan atau akuarium (Fish Bowl) yaitu Setelah memasuki materi guru membagikan dan menjelaskan fungsi kartu indeks kepada seluruh siswa; Guru membagi siswa menjadi 4-5 kelompok dan pembagian dilakukan secara heterogen (disesuaikan lagi dengan banyak siswa dan luas atau sempitnya materi); Guru membantu siswa membentuk akuarium ikan. Misalnya kelompok 1(satu) berada dibagian tengah sebagai ikan atau kelompok yang sedang berdiskusi, sedangkan kelompok yang lain berada disekelilingnya membentuk lingkaran sebagai akuarium; Guru membawakan materi mata pelajaran IPS dan semua siswa harus memperhatikan dan mendengarkan dengan baik; Setelah selesai membawakan materi guru meminta kepada setiap siswa untuk menuliskan pertanyaan pada kartu indeks pada materi yang belum dipahami atau 
dimengerti. (jika tidak cukup waktu maka bisa dijadikan PR dan tugas ini merupakan nilai tambahan); Kemudian siswa mengumpulkan kartu indeks yang sudah berisi pertanyaan dan langsung meletakan di meja guru atau tempat yang sudah disediakan; Guru mengambil beberapa kartu (disesuaikan dengan jumlah anggota kelompok) dan memberikan kepada setiap kelompok 1-2 kartu indeks yang sudah berisi pertanyaan; Guru memberikan waktu beberapa menit untuk siswa mendiskusikan jawaban. Selagi siswa berdiskusi guru dapat memantau jalannya diskusi dari luar area siswa; Setelah semua kelompok siap guru mempersilahkan kelompok 1 untuk mempersentasikan hasil diskusi sedangkan kelompok yang lain harus mendengarkan dan memperhatikan. Ini di lakukan secara bergilir; Jika semua kelompok sudah persentasi maka guru dan siswa bersama-sama lagi mendiskusikan hal atau materi yang belum jelas dipahami.

c) Kelebihan dan kekurangan teknik mangkuk ikan atau akuarium (Fish Bowl)

(1) Kelebihan Teknik mangkuk ikan atau akuarium (Fish Bowl) yaitu Siswa menjadi aktif baik di sekolah maupun di rumah; Melatih siswa untuk berpikir kritis; Siswa berani untuk tampil atau unjuk diri apalagi dengan perbedaan pendapat yang bervariasi; Poses kegiatan belajar mengajar menjadi lebih aktif dan menyenangkan; Melatih hubungan sosial dengan teman sejawat; Melatih siswa untuk menyimak dan menjadi pendengar yang baik saat orang lain sedang menyampaikan pendapatnya; Secara tidak langsung terdapat variasi tempat duduk; Setiap kelompok memiliki pencatat hasil diskusi; Guru banyak memiliki bank soal dari kumpulan kartu indeks yang sewaktuwaktu dapat digunakan.

(2) Kekurangan Teknik mangkuk ikan atau akuarium (Fish Bowl) yaitu Jika tidak diselingi dengan teknik lain maka siswa akan merasa bosan dengan teknik yang ini-ini saja; Jawaban siswa terkadang ngelantur atau tidak sesuai dengan harapan; Hanya siswa yang suka berbicara dominan yang akan mengungkapkan pendapatnya; Bagi guru yang belum menguasai kelas maka ini akan memakan waktu yang sangat lama. Ditambah dengan siswa yang tidak bisa diatur; Dalam teknik ini diharapkan guru harus terampil dalam mengemukakan pendapat secara singkat dan tepat.

2. Efektivitas Teknik Pembelajaran

a. Hakikat Pembelajaran yang Efektif

Menurut Yusuf Hadi Miarso (Uno dan Mohamad, 2012: 173) memandang bahwa pembelajaran yang efektif adalah pembelajaran yang dapat menghasilkan belajar yang bermanfaat dan terfokus pada siswa (Student Cendered) melalui penggunaan prosedur yang tepat. Pembelajaran efektif merupakan proses pembelajaran bermakna yang memiliki manfaat dan terfokus pada siswa melalui penggunaan prosedur yang tepat. Suatu proses belajar-mengajar dapat dikatakan berhasil baik, jika kegiatan belajar-mengajar tersebut dapat membangkitkan proses belajar.

b. Faktor yang Mempengaruhi Kefektifan Belajar

Terdapat beberapa faktor yang mempengaruhi keefektifan belajar siswa (Uno dan Mohamad, 2012: 198) yaitu sebagai berikut:

1) Faktor Internal Siswa yaitu faktor yang berasal dari dalam diri siswa terdiri dari dua aspek, yaitu aspek fisiologis dan aspek psikologis.

2) Pendekatan Belajar

a) Pengertian belajar yaitu kemampuan siswa untuk mengorganisasikan belajar turut mempengaruhi efektivitas belajarnya. Kemampuan siswa menerima dan memprosesnya menjadi suatu yang bermakna dapat dilakukan dengan mengorganisasi waktu belajar.

b) Hambatan Mengorganisasi Belajar, Dalam kenyataannya, semua proses tidak selalu berjalan dengan lancar, ada siswa yang mengalami hambatan dalam proses penerimaan, 
proses pengaktifan atau penguatan, proses pengolahan, kesulitan dalam proses penyimpanan, dan kesulitan dalam pemanggilan.

\section{Hakekat Pelajaran IPS SD}

Secara khusus, tujuan pendidikan IPS di sekolah dapat di kelompokkan menjadi empat komponen, sebagaimana yang dikemukakan oleh Chapin \& Messick (Susanto. 2013: 147) yaitu: 1) memberikan kepada siswa pengetahuan tentang pengalaman manusia dalam kehidupan bermasyarakat pada masa lalu, sekarang, dan masa yang akan datang; 2) menolong siswa untuk mengembangkan keterampilan untuk mencari dan mengolah atau memproses informasi; 3) menolong siswa untuk mengembangkan nilai/sikap demokrasi dalam kehidupan bermasyarakat; dan 4) menyediakan kesempatan kepada siswa untuk berperan serta dalam kehidupan sosial. Keempat tujuan ini tidak terpisah atau berdiri sendiri, melainkan merupakan kesatuan dan saling berhubungan. Dengan demikian, jelaslah bagi kita, bahwa pendidikan IPS bukanlah mata pelajaran disiplin ilmu tunggal, melainkan gabungan dari beberapa disiplin ilmu (interdisipliner).

4. Hasil Belajar

Hasil belajar yaitu perubahan-perubahan yang terjadi pada diri siswa, baik yang menyangkut aspek kognitif, afektif, psikomotor sebagai hasil dari kegiatan belajar. Secara sederhana yang dimaksud dengan hasil belajar siswa adalah kemampuan yang diperoleh anak setelah melalui kegiatan belajar. Anak yang berhasil dalam belajar adalah yang berhasil mencapai tujuan-tujuan pembelajaran atau tujuan intruksional (Susanto, 2013: 5).

Penelitian yang relevan dengan penelitian ini adalah penelitian yang dilakukan oleh:

1. Penelitian ini dilakukan oleh Husnil Khotimah S1 PGMI Universitas Islam Negeri Sultan Syarif Kasim Riau Pekanbaru Yang berjudul Penerapan Metode Pembelajaran Fishbowl Untuk Meningkatkan Aktivitas Belajar Sains Pada Siswa Kelas IV SDN 002 Pantai Cermin Kecamatan Tapung Kabupaten Kampar 1432 H/2011 M.

2. Penelitian ini bertujuan untuk mengetahui perbedaan kemampuan berdiskusi antara siswa yang mendapat pembelajaran menggunakan metode fishbowl dengan siswa yang mendapatkan pembelajaran tanpa metode fishbowl pada siswa kelas VIII di SMP Negeri 5 Sleman.

Kerangka berpikir, pada peneletian sebelumnya untuk teknik mangkuk ikan atau akuarium ini sudah pernah dilakukan dan hasilnyapun dapat meningkatkan aktivitas belajar siswa kelas IV dan teknik ini pun sudah terbukti lebih efektif dalam berdiskusi yang sudah dipaparkan dalam pembahasan sebelumnya.

Dalam proses pembelajaran penggunaan berbagai teknik, haruslah sesuai dengan tujuan pembelajaran. Untuk mencapai tujuan tersebut tentu saja hendaknya melibatkan aktivitas dan kreativitas siswa yang dikembangkan oleh guru itu sendiri. Jadi, siswa sangat berperan aktif dalam proses pembelajaran. Dengan teknik belajar mengajar ini menekankan pada siswa bagaimana belajar dan bagaimana mengelolanya, sehingga dapat dipahami oleh siswa itu sendiri. Sebagaimana yang ditemukan dalam observasi awal penelitian ini bahwa hasil belajar pada kelas V A SDN 16 Cakranegara pada pembelajaran IPS masih belum mencapai kriteria ketuntasan minimum, sehingga diperlukan tindakan untuk meningkatkan hasil belajar tersebut dengan menerapkan teknik mangkuk ikan atau akuarium (fish bowl).

Dengan teknik mangkuk ikan atau akuarium (fish bowl) di harapkan membuat siswa lebih aktif dan berkonsentrasi dalam proses pembelajaran baik disekolah dan dirumah sehingga menjadi lebih kondusif dan efektif. Maka diharapkan pada kondisi akhir penelitian ini terdapat peningkatan hasil belajar melalui teknik mangkuk ikan atau akuarium (fish bowl).

Hipotesis merupakan dugaan sementara yang masih perlu dibuktikan kebenarannya (Arikunto, 2006). Setelah mengetahui dari pengertian landasan teori tersebut maka hipotesis tindakan dalam penelitian ini adalah "Jika Teknik mangkuk ikan atau akuarium (Fish Bowl) diterapkan secara optimal maka dapat meningkatkan hasil belajar siswa pada mata pelajaran IPS Kelas V A SDN 16 Cakranegara. 


\section{METODE PENELITAN}

Lokasi penelitian ini dilaksanakan di SDN 16 Cakranegara pada kelas V A. Penelitian telah dilaksanakan pada semester genap tahun pelajaran 2016/2017. Adapun waktu pelaksanaan penelitian adalah sebagai berikut:

a. Penyusunan proposal dimulai dari 6 Desember - 13 Maret 2017.

b. Siklus I dilaksanakan pada tanggal 10 dan 13 April 2017.

c. Siklus II dilaksanakan pada tanggal 17 dan 19 April 2017.

d. Penyusunan skripsi dilaksanakan pada bulan Mei - Juni 2017.

Adapun yang menjadi subjek penelitian ini adalah siswa kelas V A SDN 16 Cakranegara yang berjumlah 24 orang yang terdiri dari 13 orang siswa laki-laki dan 11 orang siswa perempuan. Observer dalam penelitian ini adalah guru kelas V A SDN 16 Cakranegara yakni I Nyoman Budiana, S.Pd.

Faktor-faktor yang menjadi fokus dalam penelitian ini diantaranya faktor guru, yang diteliti adalah kegiatan guru dalam melakukan proses pembelajaran di kelas dengan menerapkan teknik Mangkuk Ikan atau Akuarium (Fish Bowl). Selain itu faktor siswa, yang diteliti adalah hasil belajar IPS siswa setelah mengikuti pembelajaran IPS dengan penerapan teknik Mangkuk Ikan atau Akuarium (Fish Bowl).

Variabel penelitian ini dibagi menjadi variabel harapan dan variabel tindakan. Definisi operasional variabel harapan yaitu hasil belajar IPS dalam penelitian ini adalah nilai siswa kelas V A SDN 16 Cakranegara yang di peroleh setelah siswa mengikuti kegiatan pembelajaran IPS pada materi Perjuangan mempersiapkan kemerdekaan Indonesia dan Proklamasi Kemerdekaan Indonesia dengan teknik Mangkuk Ikan atau Akuarium (Fish Bow). Definisi operasional variabel tindakan yaitu Teknik Mangkuk lkan atau Akuarium (Fish Bowl) adalah teknik pembelajaran dengan menggunakan media kartu indeks, dimana ini merupakan salah satu teknik guru untuk membuat siswa tetap belajar disekolah dan dirumah yang akan dilaksanakan di Kelas V A SDN 16 Cakranegara Tahun Pelajaran 2016/2017. Pelaksanaan Teknik Mangkuk Ikan atau Akuarium (Fish Bowl) yaitu guru membawakan materi sekaligus membagikan kartu indeks kepada semua siswa. (jika materi luas ini bisa dijadikan PR, dengan cara meminta siswa harus membuat pertanyaan pada kartu indeks) kemudian guru membagi 4-5 kelompok secara heterogen dan memberikan kartu indeks secara acak yang sudah berisi pertanyaan untuk mereka persentasikan didepan kelas ini dilakukan secara bergilir. Jika ada yang belum mengerti guru dan siswa dapat membahas secara bersama-sama.

Jenis penelitian ini adalah Penelitian Tindakan Kelas (PTK). Penelitian tindakan kelas ini dilaksanakan minimal dalam 2 siklus. Dimana pada setiap siklus meliputi empat tahapan proses, yaitu tahap perencanaan, tahap pelaksanaan, tahap pengamatan, dan tahap refleksi. Pelaksanaan Siklus I terdiri dari 2 kali pertemuan dengan alokasi waktu $3 \times 35$ menit dan Pelaksanaan Siklus II terdiri dari 2 kali pertemuan dengan alokasi waktu yang sama yaitu $3 \times 35$ menit.

Metode pengumpulan data yang digunakan sebagai berikut.

1. Sumber Data dan Jenis Data

Sumber data dalam penelitian ini berasal dari hasil belajar siswa kelas $V$ A semester genap dengan jumlah 24 orang, serta guru yang dalam hal ini yang bertindak sebagai peneliti, yaitu aktivitas guru.

a. Data kualitatif adalah data hasil observasi dan pengamatan terhadap pelaksanaan tindakan yang diperoleh dari data observer pada lembar observasi dan pengamatan selama proses pembelajaran.

b. Data kuantitatif adalah data hasil belajar siswa yang diperoleh dari hasil evaluasi dengan menggunakan tes tertulis berupa tes objektif.

2. Teknik Pengumpulan Data

a. Observasi

Observasi yang dimaksud dalam penelitian ini adalah melakukan pengamatan terhadap segenap aktivitas guru dan siswa dalam pembelajaran IPS kelas V A SDN 16 Cakranegara tahun pelajaran 2016/2017 ketika menerapakan teknik Mangkuk Ikan atau Akuarium (Fish Bow).

b. Tes Hasil Belajar 
Tes hasil belajar merupakan tes evaluasi untuk mengetahui sejauh mana pemahaman siswa.

c. Dokumentasi

Dokumentasi merupakan metode pengumpulan data yang dilakukan oleh peneliti untuk mengumpulkan data berupa RPP (Rencana Pelaksanaan Pembelajaran) yang sesuai dengan teknik Mangkuk Ikan atau Akuarium (Fish Bowl), lembar kerja kelompok, lembar evaluasi individu, dan dokumentasi setiap kegiatan guru dan siswa pada proses pembelajaran.

Instrumen yang digunakan untuk pengumpulan data yaitu:

1. Lembar Pengamatan (Observasi)

a. Lembar Observasi Aktivitas Guru

Indikator keberhasilan aktivitas guru ditandai dengan aktivitas guru minimal berkategori baik pada proses pembelajaran dengan menerapkan teknik Mangkuk Ikan atau Akuarium (Fish Bowl). Adapun aspek-aspek yang diamati adalah sebagai berikut:

1) Pelaksanaan dan kesiapan belajar

2) Pemberian aspresiasi dan motivasi kepada siswa

3) Penyampaian kepada siswa

4) Membimbing siswa dalam kegiatan diskusi kelompok dengan menggunakan teknik "Mangkuk Ikan Atau Akuarium (Fish Bow).

5) Pemberian umpan balik terhadap hasil kegiatan siswa.

6) Mengakhiri pembelajaran

b. Lembar Observasi Aktivitas Siswa

Observer akan mengamati aktivitas siswa. Indicator keberhasilan aktivitas belajar siswa minimal berkategori aktif pada proses pembelajaran. Beberapa aspek penilaian ktivitas belajar adalah sebagai berikut:

1) Kesiapan Siswa dalam Menerima Pelajaran

2) Antusiasme Siswa dalam Mengikuti Pembelajaran

3) Interaksi Siswa dengan Guru

4) Aktifitas siswa dalam berdiskusi

5) Partisipasi dalam persentasi kelompok

6) Partisipasi dalam refleksi dalam hasil belajar

Instrumen yang akan digunakan dalam penelitian ini adalah tes, dalam bentuk tes objektif yang dibuat oleh peneliti. Tes hasil belajar yang digunakan terdiri dari 15 soal tes objektif berupa 10 pilihan ganda dan 5 esai untuk setiap siklus.

Teknik analisis data yang digunakan sebagai berikut.

1. Data Hasil Belajar

a. Ketuntasan Individu

Hasil belajar merupakan hasil yang dicapai seorang individu setelah mengalami proses belajar dalam waktu tertentu. Setiap siswa dikatakan tuntas apabila memperoleh nilai $\geq 75$.

Rumus yang digunakan sebagai berikut:

$$
\mathrm{NA}=\frac{S A}{S M i} x 100
$$

(Sumber: Purwanto, 2011)

Keterangan:

$$
\begin{array}{ll}
\mathrm{NA} & =\text { Nilai Akhir } \\
\mathrm{SA} & =\text { Skor yang diperoleh siswa } \\
\mathrm{SMi} & =\text { Skor Maksimal ideal }
\end{array}
$$


b. Ketuntasan Klasikal

Rumus yang digunakan sebagai berikut:

$$
\mathrm{KK}=\frac{P}{N} x 100 \%
$$

(Sumber: Nurkancana dan PPN Sunartana, 1990)

Keterangan:

$\mathrm{KK}=$ Ketuntasan Klasikal

$\mathrm{P} \quad=$ Jumlah siswa yang memperoleh nilai $\geq 75$

$\mathrm{N} \quad=$ Jumlah siswa yang mengikuti tes

c. Menghitung Nilai Rata-Rata

Rumus yang digunakan sebagai berikut:

$$
\bar{X}=\frac{\Sigma x}{N}
$$

(Sumber: Sudjana, 2012:109)

Keterangan:

$\bar{X} \quad$ : Nilai rata-rata

$\Sigma \quad$ :Jumlah seluruh skor

$\mathrm{N} \quad$ : Subjek

Hasil nilai rata-rata yang diperoleh siswa pada Siklus I akan dibandingkan dengan hasil yang diperoleh siswa pada Siklus II untuk mengetahui peningkatan hasil belajar siswa.

2. Menghitung Hasil Observasi Kegiatan Pembelajaran

a. Data Aktivitas Guru

Untuk menentukan data hasil observasi aktivitas guru dalam pembelajaran dilakukan dengan menilai setiap deskriptor dari setiap indikator dengan mengikuti aturan:

a) Skor 3 diberikan jika guru melakukan semua atau tiga deskriptor yang telah ditetapkan dari masing-masing indikator.

b) Skor 2 diberikan jika guru melakukan dua dari deskriptor yang telah ditetapkan dari masingmasing indikator.

c) Skor 1 diberikan jika guru hanya melakukan satu dari deskriptor yang telah ditetapkan dari masing-masing indikator.

d) Skor 0 diberikan jika guru tidak melakukan deskriptor yang telah ditetapkan dari masingmasing indikator.

Menentukan Skor Aktivitas Maksimal ideal

SMi = Nilai Maksimum $x$ Jumlah Indikator Penilaian, dimana:

Banyaknya indikator yang diamati $\quad=6$

Skor maksimal setiap indikator $\quad=3$

Skor minimal setiap indikator $\quad=0$

Jadi, untuk skor maksimal ideal (SMi) adalah $6 \times 3=18$

Sedangkan skor minimal semua indikator adalah $6 \times 0=0$

e) Menentukan Mi (Mean ideal) dan SDi (Simpangan Deviasi ideal) dengan sebagai berikut:

$\mathrm{Mi}=\frac{1}{2}$ (skor tertinggi + skor terendah $)$

$\mathrm{Mi}=\frac{1}{2}(18+0)$ 


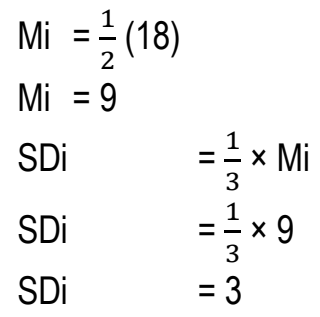

(Sumber: Nurkancana, 1990)

f) Menentukan Kriteria Aktivitas Guru

Kriteria untuk menentukan aktivitas guru ditentukan pada tabel di bawah ini:

Tabel 1. Tabel Pedoman Kriteria Aktivitas Guru

\begin{tabular}{cccc}
\hline No & \multicolumn{1}{c}{ Interval } & Skor & Kategori \\
\hline 1 & $\mathrm{Mi}+1,5 \mathrm{SDI} \leq \mathrm{M} \leq \mathrm{SMi}$ & $13,5 \leq \mathrm{M} \leq 18$ & Sangat Baik \\
\hline 2 & $\mathrm{Mi}+0,5 \mathrm{SDi} \leq \mathrm{M}<\mathrm{Mi}+1,5 \mathrm{SDi}$ & $10,5 \leq \mathrm{M}<13,5$ & Baik \\
& & & \\
\hline 3 & $\mathrm{Mi}-0,5 \mathrm{SDi} \leq \mathrm{M}<\mathrm{Mi}+0,5 \mathrm{SDi}$ & $7,5 \leq \mathrm{M}<10,5$ & Cukup Baik \\
& & & \\
\hline 4 & $\mathrm{Mi}-1,5 \mathrm{SDi} \leq \mathrm{M}<\mathrm{Mi}-0,5 \mathrm{SDi}$ & $4,5 \leq \mathrm{M}<7,5$ & Kurang Baik \\
& & & Tidak Baik
\end{tabular}
Keterangan:
$M=$ Skor aktivitas guru
$\mathrm{Mi}=$ Mean ideal
SMi $=$ Skor Maksimal ideal
$\mathrm{SDi}=$ Skor Deviasi ideal

Berdasarkan tabel di atas dapat disimpulkan bahwa aktivitas guru yang berada pada kategori cukup aktif diartikan sebagai aktivitas belajar siswa telah berlangsung secara normal.

b. Data Aktivitas Siswa

Untuk menentukan data hasil observasi aktivitas siswa secara klasikal dalam pembelajaran, dilakukan dengan menilai setiap deskriptor dari masing-masing indikator yang dinilai dengan mengikuti aturan:

a) Skor 4 diberikan jika lebih dari $75 \%$ siswa ( $\geq 18$ orang siswa dari 24 siswa) memenuhi deskriptor yang telah ditetapkan.

b) Skor 3 diberikan jika 50\% sampai dengan $74 \%$ siswa (12-17 orang siswa dari 24 siswa) memenuhi deskriptor yang telah ditetapkan.

c) Skor 2 diberikan jika 25\% sampai dengan 49\% siswa siswa (6-11 orang siswa dari 24 siswa) memenuhi deskriptor yang telah ditetapkan.

d) Skor 1 diberikan jika kurang dari 25\% siswa siswa (5 orang siswa dari 24 siswa) memenuhi deskriptor yang telah ditetapkan.

e) Menentukan Skor Aktivitas Maksimal Ideal (SMI)
Banyaknya indikator yang diamati
$=6$
Skor maksimal setiap deskriptor
$=4$
Banyaknya deskriptor
$=18$
Jadi, untuk skor maksimal ideal (SMi) adalah $4 \times 18=72$

f) Menentukan Mean Ideal (Mi) dan Standar Deviasi Ideal (SDI) 


$$
\begin{aligned}
\mathrm{Mi} & =\frac{1}{2} \times(\text { skor tertinggi }+ \text { skor terendah }) \\
& =\frac{1}{2} \times(72+18) \\
& =45 \\
\mathrm{SDi} & =\frac{1}{3} \times S M i \\
& =\frac{1}{3} \times 45 \\
\mathrm{SDi} & =15
\end{aligned}
$$

(Sumber: Nurkancana, 1990)

g) Menentukan Kriteria Aktivitas Siswa

Kriteria untuk menentukan aktivitas siswa ditentukan pada tabel di bawah ini:

Tabel 2. Pedoman Kriteria Aktivitas Siswa

\begin{tabular}{clcc}
\hline No & \multicolumn{1}{c}{ Interval } & Skor & Kategori \\
\hline 1 & $\mathrm{Mi}+1,5 \mathrm{SDI} \leq \mathrm{M} \leq \mathrm{SMi}$ & $67,5 \leq \mathrm{M} \leq 72$ & Sangat Aktif \\
\hline 2 & $\mathrm{Mi}+0,5 \mathrm{SDi} \leq \mathrm{M}<\mathrm{Mi}+1,5 \mathrm{SDi}$ & $52,5 \leq \mathrm{M}<67,5$ & Aktif \\
\hline 3 & $\mathrm{Mi}-0,5 \mathrm{SDi} \leq \mathrm{M}<\mathrm{Mi}+0,5 \mathrm{SDi}$ & $37,5 \leq \mathrm{M}<52,5$ & Cukup Aktif \\
\hline 4 & $\mathrm{Mi}-1,5 \mathrm{SDi} \leq \mathrm{M}<\mathrm{Mi}-0,5 \mathrm{SDi}$ & $22,5 \leq \mathrm{M}<37,5$ & Kurang Aktif \\
\hline 5 & $0 \leq \mathrm{M}<\mathrm{Mi}-1,5 \mathrm{SDi}$ & $0 \leq \mathrm{M}<22,5$ & Tidak Aktif \\
\hline
\end{tabular}

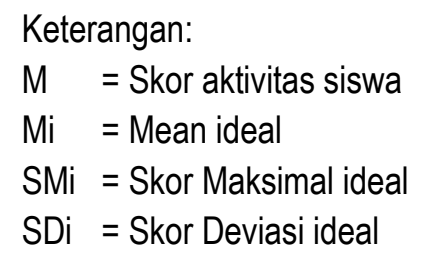

Berdasarkan tabel di atas, untuk data aktivitas siswa, dikatakan berhasil apabila minimal berkategori aktif atau mengalami peningkatan rata-rata skor aktivitas dari siklus sebelumnya.

Indikator penelitian ini adalah pencapaian aktivitas guru, hasil belajar IPS dengan ketentuan sebagai berikut:

1. Hasil belajar IPS siswa mencapai nilai kriteria ketuntasan minimal $(\mathrm{KKM}) \geq 75$ dan ketuntasan klasikal sebesar $85 \%$.

2. Terjadi peningkatan aktivitas belajar siswa setelah dilakukan pembelajaran dengan menerapkan teknik Mangkuk Ikan atau Akuarium (Fish Bowl). Aktivitas belajar siswa minimal aktif.

3. Aktivitas guru minimal berada pada kategori baik selama proses pembelajaran dengan menggunakan teknik Mangkuk Ikan atau Akuarium (Fish Bowl)

\section{HASIL PENELITAN DAN PEMBAHASAN}

Hasil penelitian yang diperoleh sebagai berikut.

1. Siklus I

a) Jumlah skor aktivitas guru sebesar 12,5 dengan kategori Baik.

b) Jumlah skor aktivitas siswa sebesar 53 dengan kategori Cukup Aktif.

c) Ketuntasan hasil belajar siswa terlihat dari 24 orang siswa terdapat 7 orang siswa yang belum tuntas sedangkan siswa yang tuntas ada 17 orang siswa, adapun nilai tertinggi 90 dan nilai terendah 51. Persentase ketuntasan hasil belajar siswa yaitu $70,83 \%$. Hasil yang diperoleh pada Siklus I masih belum berhasil, hal ini dapat dilihat dari nilai 
persentase ketuntasan yang mendapat $70,83 \%$ dari 24 orang siswa. Maka dari itu perlu dilakukan perbaikan pada siklus berikutnya.

2. Siklus II

a) Jumlah skor aktivitas guru sebesar 17,5 dengan kategori Sangat Baik.

b) Jumlah skor aktivitas siswa sebesar 58,5 dengan kategori Aktif.

c) Ketuntasan hasil belajar siswa terlihat dari 24 orang siswa terdapat 3 orang siswa yang belum tuntas sedangkan siswa yang tuntas ada 21 orang siswa, adapun nilai tertinggi 99 dan nilai terendah 66. Persentase ketuntasan hasil belajar siswa yaitu $87,5 \%$.

Adapun ringkasan dari hasil penelitian yang memuat data hasil observasi aktivitas guru, aktivitas siswa, dan data hasil belajar pada Siklus I dan Siklus II dapat dilihat pada tabel dibawah ini.

Tabel 3. Aktivitas dan Hasil Belajar Guru dan Siswa Siklus I dan Siklus II

\begin{tabular}{ccccccc}
\hline Siklus & \multicolumn{2}{c}{ Aktivitas Siswa } & \multicolumn{2}{c}{ Aktivitas Guru } & \multicolumn{2}{c}{ Hasil Belajar } \\
\cline { 2 - 6 } & Skor & Kategori & Skor & Kategori & $\begin{array}{c}\text { Jumlah Siswa } \\
\text { yang Tuntas }\end{array}$ & Persentase \\
\hline I & 53 & $\begin{array}{c}\text { Cukup } \\
\text { Aktif }\end{array}$ & 12,5 & Baik & 17 & $70,83 \%$ \\
\hline II & 58,5 & Aktif & 17,5 & Sangat Baik & 21 & $87,5 \%$ \\
\hline \multicolumn{7}{c}{ Peningkatan persentase } \\
\hline
\end{tabular}

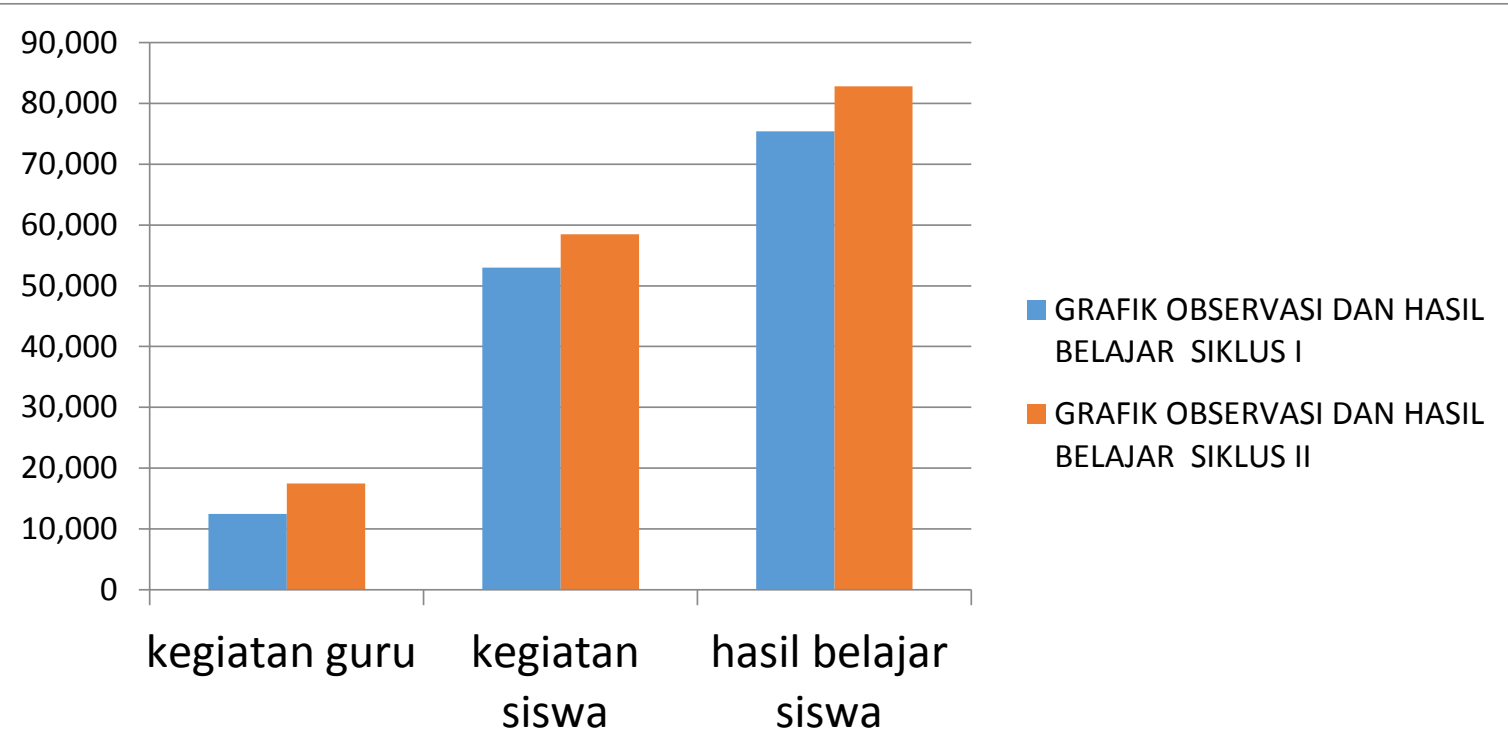

\section{KESIMPULAN}

Dari hasil penyajian data dan pembahasan sebelumnya maka dapat disimpulkan, bahwa siklus I diperoleh nilai rata-rata 75,375 dengan ketuntasan klasikal 70,83\% dan skor rata-rata aktivitas siswa 53 dengan kategori cukup aktif. Pada siklus II data hasil belajar dan aktivitas siswa mengalami peningkatan yakni rata-rata 82,791 dengan ketuntasan klasikal 87,5\% dan skor rata-rata aktivitas belajar siswa 58,5 dengan kriteria aktif. Dengan demikian dapat disimpulkan bahwa Efektivitas Teknik Mangkuk Ikan atau Akuarium (Fish Bowl) dapat meningkatkan hasil belajar IPS siswa kelas V A SDN 16 Cakranegara Tahun Pelajaran 2016/2017. 


\section{DAFTAR PUSTAKA}

Asmani, M. Jamal. 2011. 7 Tips Aplikasi Pakem. Jogjakarta: DIVA Press.

Aries, E. 2011. Assesmen Dan Evaluasi. Yogyakarta: Adytia Media Publising.

Arikunto, S. 2010. Prosedur Penelitian. Jakarta: Rineka Cipta.

Azizah R. Anindita. 2014. Penggunaan Metode Active Learning Tipe Card Sort

Untuk Meningkatkan Keaktifan dan Prestasi Belajar IPS Siswa Kelas IV SD Negeri Sendangsari. Skripsi.

Pendidikan Guru Sekolah Dasar Universitas Negeri Yogyakarta. https://www.google.com, di akses pada tanggal 25 januari 2017.

Alma, Buchari, dkk. 2014. Guru Professional. Bandung: Alfabeta.

Huda, Miftahul. 2015.Cooperative Learning. Yogyakarta: Pustaka Pelajar.

Khotimah, Husnil. 2011. Penerapan Metode Pembelajaran Fishbowl Untuk Meningkatkan Aktivitas Belajar Sains

Pada Siswa Kelas IV SDN 002 Pantai Cermin Kecamatan Tapung Kabupaten Kampar. Skripsi. Pendidikan

Guru Madrasah Ibtidaiyah Universitras Islam Negeri Sultan Syarif Kasim Riau. https://www.google.com, diakses tanggal 17 Desember 2016.

Nurkancana, Wayan dan Sunartana. 1990. Evaluasi Hasil Belajar. Surabaya: Usaha Nasional.

Qur'anni,E Afriliya. 2013. Pengaruh Metode Team Quiz Terhadap Minat Belajar dan Pencapaian Kompetensi Menghadapi Situasi Darurat Pada Mata Pelajaran K3lh Di Smk Negeri 2 Godean. Skripsi. Program Studi Pendidikan Teknik Busana Universitas Negeri Yogyakarta. https://www.google.com, diakses tanggal 25 januari 2017.

Sanjaya, Wina. 2006. Strategi Pembelajaran. Jakarta: Kencana.

Sari, Melda, Supriyadi, Dan Sudirman A. 2014. Penerapan Strategi Active Learning Tipe Everyone Is Ateacher Here Untuk Meningkatkan Hasil Belajar. Jurnal. Fakultas Keguruan Dan IImu Pendidikan Universitas Lampung. https://www.google.com, diakses tanggal 25 januari 2017.

Silberman, Mel. 2010. 101 Cara Pelatihan \& Pembelajaran Aktif. Jakarta Barat: Indeks.

Sudjana, Nana. 2014. Dasar-Dasar Proses Belajar Mengajar. Bandung: Sinar Baru Algensindo.

Suprijono, Agus. 2014. Cooperative Learning. Yogyakarta: Pustaka Pelajar.

Susanto. 2013. Teori Belajar \& Pembelajaran Di Sekolah Dasar. Jakarta: Kencana.

Trianto. 2011. Model Pembelajaran Inovatif Berorientasi Kontroktivis. Jakarta: Prestasi Pustaka

Uno, B Hamzah dan Mohamad, Nurdin. 2012. Belajar dengan Pendekatan PAILKEM.Jakarta: Bumi Aksara.

Utami, B. Rahmawati. 2012. Keefektifan Metode Fishbowl Terhadap Pembelajaran Berdiskusi Pada Siswa Kelas Viii Smp Negeri 5 Sleman. Skripsi. Pendidikan Bahasa Dan Sastra Indonesia Universitas Negeri Yogyakarta https://www.google.com, diakses tanggal 26 november 2016.

Wahidah, S, Susan. 2014. Penerpan Metode "STEAVES BERHTO" (STUDENT TEAM-ACHIEVEMENT DIVISIONS DAN NUMBERED HEADS TOGETHER) untuk meningkatkan hasil belajar IPS siswa keas IVC SDN 1 kediri Tahun Pelajaran 2013/2014. Skripsi. Keguruan dan IImu Pendidikan, Pendidikan Guru Sekolah Dasar. Universitas Mataram.

Warsono dan Hariyanto. 2013. Pembelajaran Aktif. Bandung: Remaja Rosdakarya. 